\title{
A Method of Criteria Selection for Transformer Condition Assessment You Song ${ }^{1, a}$, Zhengqi Wen ${ }^{1, b^{*}}$, Wei Du ${ }^{1, d}$ and Qishen LV ${ }^{2, d}$ \\ ${ }^{1}$ NARI Group Corporation(State Grid Electric Power Research Institute), Nanjing 210003, China \\ ${ }^{2}$ Shenzhen Power Supply Bureau Co., Ltd., Shenzhen 518001, China; a30661576@qq.com,,wzqcsu@163.com, c273886771@qq.com, 'dgupenglv@qq.com
}

\section{Keywords: Transformer; Condition assessment; FMEA; AHP}

\begin{abstract}
At the present stage, the selection of criteria for transformer condition assessment is mostly based on experience. The lack of accurate and effective synthetic indicators leads to the potential faults of transformers difficult to obtain timely feedback. In this paper, a method of criteria optimization based on analytic hierarchy process (AHP) was proposed. Firstly, FMEA (failure mode and effects analysis) was used to obtain the degree of occurrence, severity and detection methods of various common faults in transformers. Then, the AHP was used to prioritize the detection methods of common faults based on FMEA. Thus, the optimization model of transformer condition assessment was established. Finally take this method of transformer condition assessment as an example, to prove the feasibility of this method.
\end{abstract}

\section{Introduction}

As primary equipment in the electrical power system, reliable transformer provides guarantee to the safe operation of the overall system. Currently, the assessment on the condition of the equipment is through the multi-information fusion transformer condition assessment model, the establishment of which is mainly based on the test data (including preventive test, ex-works test, handover test, diagnostic test, energized test and on-line monitoring) and data gained from routine inspection, operating environment, history file and familial defect of the equipment. Based on this, extensive studies have been carried out on some modern comprehensive evaluation algorithms. Such as fuzzy comprehensive evaluation ${ }^{[1]}$, evidence theory ${ }^{[2]}$, grey hierarchy analytic evaluation model ${ }^{[3]}$, Bayesian network $^{[4]}$, etc. The application of those methods not only has greatly accelerated the development of studies on the condition assessment of the transformer, but also has played an important role in practical use. But a comprehensive and effective selection method of criteria was missing during the establishment of the assessment model which resulted in the lack of overall consideration of the source of the criteria, the sensitivity to the failure mode, the reliability of the testing method and economical efficiency, etc and eventually affected the effectiveness of the condition assessment model in practical use. This article is based on actual operation and maintenance data record and expert advice, by using failure mode and effects analysis (FMEA), comprehen sively analyzes the characteristics of the transformer's failure modes and sets up detection method optimal comprehensive decision-making model for each failure mode using analytic hierarchy process (AHP). Finally, based on the results obtained from the FMEA and AHP, the model of selection optimal criteria is established and is being used as an important reference index for the selection of criteria for transformer condition assessment.

\section{Failure mode and effect analysis}

\section{Transformer failure statistics}

Transformer's failure types vary, so are the complex causes, such as the defects in manufacturing and installing, inappropriate operation condition and errors in operation, etc. This article obtains common failure modes of our transformers during operation by statistically analyzing years of State Grid's transformers failure cases ${ }^{[5-6]}$, and takes the foresaid as the foundation for FMEA analysis. According to the statistics, the main body and bushing of the transformer are the two parts prone to breaking 
down, which accounted for $67 \%$ of all the failure modes, and failures in mechanical property, thermal property, insulating property and accessories failures (including bushing, tapping switch, cooling system and non-electrical quantity protection) accounted for $18 \%, 10 \%, 15 \%$ and $57 \%$, respectively. Among them, mechanical failures mainly involve winding deformation, clapping loosening and vibration, thermal failures mainly involve the over heating of the iron core, poor contact of the conductive circuits and common overheating (including cooler breakdown, oil duct blocking, fan malfunction, etc.); insulating failures mainly involve the breakdown, damping and oil degradation of the oil paper for the winding turns, interlayer and plies of the transformer coils; accessories failures mainly involve the bushing, including flashover, overheating of the capacitor core, imperfect grounding of the tap of bushing, etc.

\section{Failure mode and effect analysis}

By adopting the FMEA, this article analyzes the possible failure mode that might happen to the transformer and its effect on the whole system, including failure modes, causes, occurrence level, its severity, effect, failure detection method, offsetting measure ${ }^{[9]}$, etc. Because of the insufficient data and un-standardized recording of the failure modes, we combined the available data and experience of the experts and field staff when determining the occurrence level of the failure mode, see Table 1 for details. Among them, probability refers to the proportion of each failure mode in all failure modes of the transformer. Severity is the measurement of the effect the failure mode might have on the system, determined by qualitative empirical analyses method. There are 5 grades in total; see Table 2 . Based on the results of the statistical analysis of the transformer's failure modes and experience from the experts, the FMEA outcome of the failure modes for mechanical property and thermal property are shown in Table $3^{[7-9]}$.

Table1. Occurrence of failure modes

\begin{tabular}{|c|c|c|c|c|c|}
\hline \multirow{2}{*}{$\begin{array}{l}\text { Occurrence } \\
\text { level }\end{array}$} & \multirow{2}{*}{$\begin{array}{l}\text { Probability } \\
\text { range }\end{array}$} & \multirow[t]{2}{*}{ Occurrence } & \multicolumn{2}{|r|}{ Severity level } & Severity \\
\hline & & & \multirow{4}{*}{ Fatal } & \multirow{8}{*}{$\begin{array}{l}\text { Serious damage to the equipment, grid } \\
\text { safety is affected, immediate shutdown } \\
\text { and emergency maintenance are needed, } \\
\text { with long repair cycle. } \\
\text { Obvious damage to the equipment, } \\
\text { obvious function degradation of the } \\
\text { system, se vere damage to partial } \\
\text { functions, prompt maintenance is } \\
\text { required. }\end{array}$} & \multirow{5}{*}{$9-10$} \\
\hline \multirow{2}{*}{ Very high } & $\geq 0.5$ & 10 & & & \\
\hline & $0.4 \sim 0.5$ & 9 & & & \\
\hline \multirow{2}{*}{ High } & $0.3 \sim 0.4$ & 8 & & & \\
\hline & $0.2 \sim 0.3$ & 7 & \multirow{4}{*}{ Serious } & & \\
\hline \multirow{3}{*}{ Moderate } & $0.1 \sim 0.2$ & 6 & & & \multirow[t]{3}{*}{$7-8$} \\
\hline & $0.05 \sim 0.1$ & 5 & & & \\
\hline & $0.01 \sim 0.05$ & 4 & & & \\
\hline \multirow{2}{*}{ Low } & $0.005 \sim 0.01$ & 3 & \multirow[t]{2}{*}{ Fairly serious } & \multirow{2}{*}{$\begin{array}{l}\text { Obvious defect, function degradation of } \\
\text { the system, partial function deteriorating. } \\
\text { Defect emerges function degradation of }\end{array}$} & \multirow[t]{2}{*}{$5-6$} \\
\hline & $0.001 \sim 0.005$ & 2 & & & \\
\hline \multirow[t]{2}{*}{ Rare } & $<0.001$ & 1 & Critical & the system, partial function deteriorating, & $3-4$ \\
\hline & & & Mild & $\begin{array}{l}\text { System functions normally, defect occurs, } \\
\text { no power off during maintenance. }\end{array}$ & $1-2$ \\
\hline
\end{tabular}

\section{Optimal selection of the failure mode detection method based on AHP}

\section{The rationale of the AHP}

AHP is mainly used to determine the decision making in the overall assessment, including the structure of the hierarchy, the structure judgment matrix, relative weight calculation and consistence check. First is to set up the judgment matrix A on the basis of hierarchical structure model. Assume there are $\mathrm{N}$ factors at the same hierarchy, then $A=\left(\mathrm{a}_{i j}\right)_{N \times N}, a_{i j}$ is the importance of factor $i$ and factor $j$ to a certain index. The importance is measured by a scale of 1 to $9^{[10]}$; and then this article calculates judgment matrix A's largest characteristic root $\lambda_{\max }$ and corresponding eigenvector $\omega=\left(\omega_{1}, \omega_{2}, \ldots, \omega_{N}\right)^{T}$ by using adding method. And finally use the consistency ratio CR and formula (1) and (2) to do the calculation, when $\mathrm{CR}<0.1$, its consistency falls in the acceptable range, and we can get the weight vector after normalizing the eigenvector $\boldsymbol{\omega}$, otherwise the judgment matrix A needs to be adjusted. 


$$
\begin{aligned}
& C I=\frac{\lambda_{\max }-N}{N-1} \\
& C R=\frac{C I}{R I}
\end{aligned}
$$

In the formula: $\mathrm{CI}$ is the consistence judgment index; $\mathrm{RI}$ is the random consistency index at the same hierarchy, refer to reference [10] for evaluation criterion.

\begin{tabular}{|c|c|c|c|c|c|c|}
\hline & $\begin{array}{l}\text { Failure } \\
\text { mode }\end{array}$ & Failure causes & Effects of the failure & $\begin{array}{l}\text { Severit } \\
\mathrm{y}\end{array}$ & $\begin{array}{l}\text { Concurrenc } \\
\mathrm{y}\end{array}$ & Detection method \\
\hline \multirow{5}{*}{$\begin{array}{l}\text { Mechanica } \\
1 \text { failure }\end{array}$} & $\begin{array}{l}\text { Loosening } \\
\text { of clapping }\end{array}$ & $\begin{array}{l}\text { Manufacturing } \\
\text { process, vibration }\end{array}$ & $\begin{array}{l}\text { Loosening of the } \\
\text { iron core, main } \\
\text { transformer outage }\end{array}$ & 9 & 4 & $\begin{array}{l}\text { leakage reactance, } \\
\text { capacitance and } \\
\text { vibration } \\
\text { measurement }\end{array}$ \\
\hline & $\begin{array}{l}\text { Winding } \\
\text { deformation }\end{array}$ & $\begin{array}{l}\text { Short-circuit impact, } \\
\text { material defect }\end{array}$ & $\begin{array}{l}\text { Winding damage, } \\
\text { main transformer } \\
\text { outage }\end{array}$ & 9 & 6 & $\begin{array}{l}\text { leakage reactance, } \\
\text { FRA, capacitance }\end{array}$ \\
\hline & Vibration & $\begin{array}{l}\text { Iron core vibration } \\
\text { caused by hysteresis } \\
\text { leads to the vibration } \\
\text { of the winding which } \\
\text { causes flux leakage } \\
\text { that leads to the oil } \\
\text { tank vibration. }\end{array}$ & $\begin{array}{l}\text { Dielectric } \\
\text { breakdown, } \\
\text { loosening parts, } \\
\text { Main transformer } \\
\text { outage }\end{array}$ & 6 & 7 & $\begin{array}{l}\text { DGA } \\
\text { noise measurement }\end{array}$ \\
\hline & $\begin{array}{l}\text { Iron core } \\
\text { multipoint } \\
\text { grounding }\end{array}$ & $\begin{array}{l}\text { Foreign objects } \\
\text { inside, iron core } \\
\text { makes contact with } \\
\text { the cover or damping } \\
\text { of the cardboard } \\
\text { paper at the bottom } \\
\text { of the clamp }\end{array}$ & $\begin{array}{l}\text { Partial overheating, } \\
\text { iron core damage }\end{array}$ & 5 & 6 & $\begin{array}{l}\text { DGA, exciting } \\
\text { current, iron core } \\
\text { insulation resistor } \\
\text { tan } \delta / \text { power factor } \\
\text { iron core ground } \\
\text { current }\end{array}$ \\
\hline & $\begin{array}{l}\text { Iron core } \\
\text { partial } \\
\text { short-circuit }\end{array}$ & $\begin{array}{l}\text { Insulation damage } \\
\text { between silicon steel } \\
\text { sheets or abnormal } \\
\text { lapping }\end{array}$ & $\begin{array}{l}\text { Partial overheating, } \\
\text { iron core damage }\end{array}$ & 5 & 6 & DGA, no-load loss \\
\hline \multirow[t]{3}{*}{$\begin{array}{l}\text { Thermal } \\
\text { failure }\end{array}$} & $\begin{array}{l}\text { Flux leakage } \\
\text { overheating }\end{array}$ & $\begin{array}{l}\text { Design flaw, flux } \\
\text { leakage eddy current }\end{array}$ & $\begin{array}{l}\text { Acceleration of the } \\
\text { insulation aging, } \\
\text { energy efficiency } \\
\text { dropping }\end{array}$ & 4 & 7 & $\begin{array}{l}\text { DGA, infrared } \\
\text { temperature } \\
\text { measurement }\end{array}$ \\
\hline & $\begin{array}{l}\text { Poor contact } \\
\text { of } \\
\text { conducting } \\
\text { loop }\end{array}$ & Poor welding & $\begin{array}{l}\text { Wire burnout due to } \\
\text { partial overheating }\end{array}$ & 7 & 7 & $\begin{array}{l}\text { DGA, infrared } \\
\text { temperature } \\
\text { measurement, direct } \\
\text { current resistance, } \\
\text { furfural in the oil }\end{array}$ \\
\hline & $\begin{array}{l}\text { Common } \\
\text { overheating }\end{array}$ & $\begin{array}{l}\text { Cooler breakdown, } \\
\text { oil duct blocking, fan } \\
\text { malfunction }\end{array}$ & $\begin{array}{l}\text { Acceleration of the } \\
\text { insulation aging, } \\
\text { might result in the } \\
\text { shutdown of the } \\
\text { transformer }\end{array}$ & 6 & 8 & $\begin{array}{l}\text { DGA, temperature of } \\
\text { the top layer oil, } \\
\text { routine inspection }\end{array}$ \\
\hline
\end{tabular}

Table3. Failure mode and effects analysis for transformer mechanical and thermal failures

Note: FRA: Frequency Response Analysis; DGA: Dissolved Gas-in-oil Analysis.

\section{Optimal selection of the detection method for failure modes}

Optimal selection is used to rank the detection method in accordance with its merit for each failure mode in the FMEA Table This article takes into consideration the detection of the sensitivity (S), detectability (D), reliability (R) and cost (C); see Table 4 for the quantification regulation for each factor. The priority index (P) is obtained by using AHP. See Fig 1 for the optimal criteria selection hierarchical structure model for transformer's failure mode. The judgment matrix $\mathbf{A}$ is established in 
accordance with experts experience and the quantification regulation, and the augmented matrix $[\mathbf{A} \mid \mathbf{W}]$ in Table5 is established by calculating each factor's weight vector (W) with relative weight calculation method. According to the theory of consistency check, the consistence ratio of the judgment matrix $\mathrm{CR}=0.00632<0.1$, it meets the requirement for consistence check.

Table 4. Evaluation criteria for factors considered in priority index

\begin{tabular}{|c|c|c|}
\hline Item & Grade & Score \\
\hline \multirow{3}{*}{ Sensitivity } & $\begin{array}{l}\text { Good recognition } \\
\text { performance }\end{array}$ & $7-10$ \\
\hline & $\begin{array}{l}\text { Fairly good recognition } \\
\text { performance }\end{array}$ & $4-6$ \\
\hline & $\begin{array}{l}\text { Average recognition } \\
\text { performance }\end{array}$ & $1-3$ \\
\hline \multirow{3}{*}{ Detectability } & $\begin{array}{l}\text { Power-off factory } \\
\text { detection }\end{array}$ & $7-10$ \\
\hline & Power-off site detection & $4-6$ \\
\hline & On-line detection & $1-3$ \\
\hline & Universal & $7-10$ \\
\hline \multirow[t]{3}{*}{ Reliability } & General & $4-6$ \\
\hline & Under study & $1-3$ \\
\hline & Power off & $7-10$ \\
\hline \multirow[t]{3}{*}{ Cost } & $\begin{array}{l}\text { Live and on-line } \\
\text { monitor }\end{array}$ & $4-6$ \\
\hline & Routine inspection & $1-3$ \\
\hline & $\begin{array}{l}\text { Priority index for the } \\
\text { detection method }\end{array}$ & \\
\hline Sensitivity & Detectability & Cost \\
\hline & $\begin{array}{l}\text { ction } \\
\operatorname{lod} 1\end{array}$ & \\
\hline
\end{tabular}

Figure 1. Hierarchical model of fault detection method

Table5. Judgment matrix and weight of relevant factors of failure mode detection method

\begin{tabular}{llllll}
\hline Index & $\mathrm{S}$ & $\mathrm{D}$ & $\mathrm{R}$ & $\mathrm{C}$ & Weight \\
\hline $\mathrm{S}$ & 1.000 & 1.000 & 2.000 & 4.000 & 0.378 \\
$\mathrm{D}$ & 1.000 & 1.000 & 0.500 & 2.000 & 0.225 \\
$\mathrm{R}$ & 0.500 & 2.000 & 1.000 & 3.000 & 0.296 \\
$\mathrm{C}$ & 0.250 & 0.500 & 0.333 & 1.000 & 0.102 \\
\hline
\end{tabular}

Assume the quantized index vector and weight vector for sensitivity, difficulty in detection, reliability and cost are $\boldsymbol{F}=(S, D, R, C)$ and $\boldsymbol{W}=\left(\omega_{1}, \omega_{2}, \omega_{3}, \omega_{4}\right)$ respectively, then priority index

$$
P=\boldsymbol{W} \cdot \boldsymbol{F}
$$

\section{Optimal criteria selection method for transformer condition assessment}

According to the occurrence level, severity and priority index for the failure mode detection method, the importance index of the criteria for the transformer can be acquired. Rank the importance index by its value and choose those in the front as the key characteristic quantity in the transformer condition assessment. The criteria obtained by this method can effectively reflect the potential failure mode of the transformer, and those assessment data is relatively easier to acquire.

Assume the characteristic quantity set of transformer $\mathbf{T}=\left\{X_{1}, X_{2}, \ldots, X_{N}\right\}$, failure mode set $\mathbf{M}=\left\{\mathrm{M}_{1}, \mathrm{M}_{2} \ldots \mathrm{M}_{\mathrm{L}}\right\}$, the characteristic quantity $i$ to failure mode $j$ 's priority index is $P_{i j}$, the occurrence level and severity for failure mode $j$ are $O_{j}$ and $E_{j}$ respectively. Importance index vector $K$ is: 


$$
K=\left[\begin{array}{c}
K_{1} \\
K_{2} \\
\vdots \\
K_{N}
\end{array}\right]=\left[\begin{array}{cccc}
P_{11} & P_{12} & \cdots & P_{1 L} \\
P_{21} & P_{22} & \cdots & P_{2 L} \\
\vdots & \vdots & \cdots & \vdots \\
P_{N 1} & P_{N 2} & \cdots & P_{N L}
\end{array}\right] \times\left[\begin{array}{c}
O_{1} \times E_{1} \\
O_{2} \times E_{2} \\
\vdots \\
O_{L} \times E_{L}
\end{array}\right]
$$

In the formula, $K_{i}$ is the importance index of characteristic quantity $i$, which is normalized:

$$
K_{j}^{\prime}=\frac{K_{j}}{\sum_{i=1}^{N} K_{i}} * 100 \%
$$

\section{Practical application}

Following is an example of selection of the criteria for mechanical property and thermal property for assessment of the transformer condition by using the method offered in this article.

(1) Failure mode analysis

A failure analysis table is made on the basis of statistical analysis of transformer failure modes and experience from the experts. Refer to above failure mode and effect analysis for the detailed analysis method. See Table 3 for the mechanical property and thermal failure mode analysis.

(2) Calculation of the priority index for the failure mode detection method.

Rate the sensitivity, detectability, reliability and cost for the leakage reactance of the winding deformation detection criteria, and the scores are 7,2, 9, 2 respectively, and the priority index $\mathrm{P}=5.961$. Priority indexes of criteria for the detection of other failure mode can be obtained in the same manner. See Table 6 for the result. The detection method for each failure mode and its priority are shown in the Table.

\begin{tabular}{|c|c|c|c|c|c|}
\hline \multirow{2}{*}{ Failure Category } & \multirow{2}{*}{ Failure mode } & \multirow{2}{*}{ Severity } & \multirow{2}{*}{ Concurrency } & \multicolumn{2}{|c|}{ Priority index for different detection method } \\
\hline & & & & Detection items & $\mathrm{P}$ \\
\hline \multirow{9}{*}{ Mechanical failure } & \multirow{4}{*}{ Loosening of clapping } & \multirow{4}{*}{9} & \multirow{4}{*}{4} & Short-circuit impedance & 4.449 \\
\hline & & & & Capacitance & 5.747 \\
\hline & & & & Vibration measurement & 5.318 \\
\hline & & & & Noise measurement & 5.217 \\
\hline & \multirow{3}{*}{ Winding deformation } & \multirow{3}{*}{9} & \multirow{3}{*}{6} & Short-circuit impedance & 5.961 \\
\hline & & & & FRA & 6.043 \\
\hline & & & & Capacitance & 4.613 \\
\hline & \multirow{3}{*}{ Vibration } & \multirow{3}{*}{6} & \multirow{3}{*}{7} & DGA & 6.581 \\
\hline & & & & Noise measurement & 5.441 \\
\hline \multirow{15}{*}{ Thermal failure } & & & & DGA & 6.203 \\
\hline & \multirow{4}{*}{$\begin{array}{l}\text { Loop current between } \\
\text { the iron core and ground }\end{array}$} & \multirow{4}{*}{5} & \multirow{4}{*}{6} & Exciting current & 5.268 \\
\hline & & & & Iron core insulation resistance & 3.857 \\
\hline & & & & Dielectric loss and power factor & 3.775 \\
\hline & & & & Iron core grounding current & 7.879 \\
\hline & \multirow{2}{*}{$\begin{array}{l}\text { Iron core internal loop } \\
\text { current }\end{array}$} & \multirow{2}{*}{5} & \multirow{2}{*}{6} & DGA & 6.203 \\
\hline & & & & No load loss & 4.991 \\
\hline & \multirow[t]{2}{*}{$\begin{array}{l}\text { Flux leakage } \\
\text { overheating }\end{array}$} & \multirow[t]{2}{*}{4} & \multirow[t]{2}{*}{7} & $\begin{array}{l}\text { DGA } \\
\text { Infrared } \\
\text { measurement }\end{array}$ & 6.581 \\
\hline & & & & DGA & 7.715 \\
\hline & \multirow{4}{*}{$\begin{array}{l}\text { Poor contact of } \\
\text { conducting loop }\end{array}$} & \multirow[t]{4}{*}{7} & \multirow[t]{4}{*}{7} & $\begin{array}{l}\text { Infrared } \\
\text { measurement }\end{array}$ & 6.888 \\
\hline & & & & DC resistance & 6.358 \\
\hline & & & & Furfural in the oil & 4.461 \\
\hline & & & & DGA & 6.959 \\
\hline & \multirow[t]{2}{*}{ Common overheating } & \multirow[t]{2}{*}{6} & \multirow[t]{2}{*}{8} & Top layer oil temperature & 7.622 \\
\hline & & & & Routine inspection & 7.274 \\
\hline
\end{tabular}

Table 6. Severity and occurrence of failure modes and priority index of detection methods 


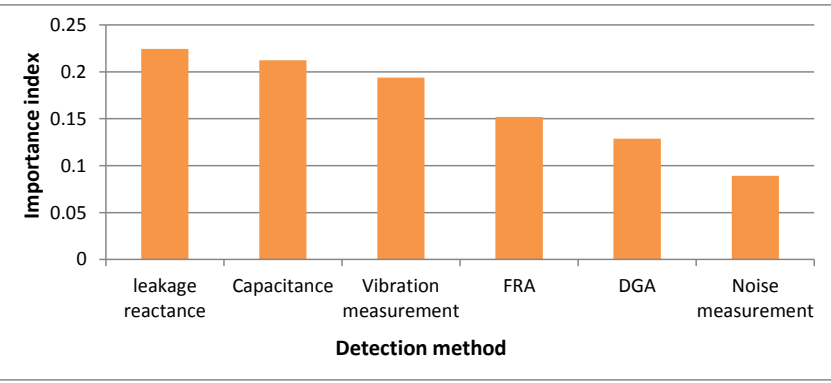

Fig2.Optimal criteria for mechanical properties

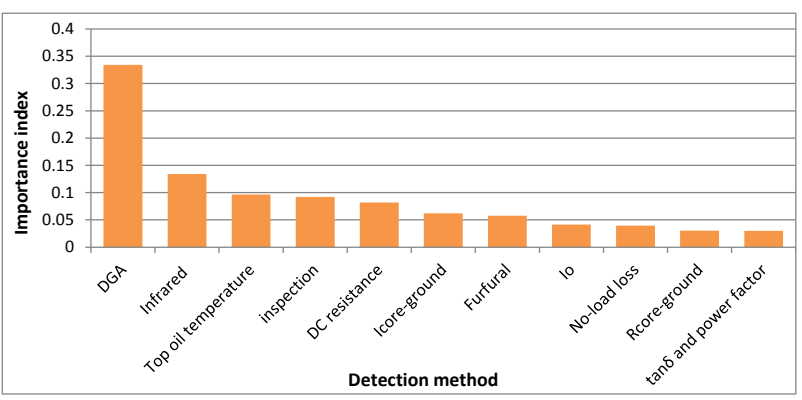

Fig3. Optimal criteria for thermal properties

\section{Conclusions}

Aiming at the criteria selection for transformer condition assessment, this article offers a quantitative index model, first by analyzing the main failure modes during the transformer's operation with FMEA method, combined with expert's experience and case study to acquire the priority index for the occurrence level, severity and detection method. Finally an importance assessment model for the criteria was established by using the 3 indexes. It ranks the criteria according to its importance and offers a valuable reference for the criteria selection for transformer condition assessment. Practice has proved its feasibility and operability. It provides effective guidance in selecting criteria for the assessment model. It has great value in engineering application. However, this method involves a great number of index quantification, and necessary adjustments should be made according to actual situation so that it can better perform its practical value in engineering application.

\section{References}

[1] LUO Si-jia, LIAO Rui-jin , WANG You-yuan, et al. Fuzzy synthetic evaluation of power transformer condition with variable weights [J]. High Voltage Engineering, 2007, 33(8): 107-108.

[2] TANG W H, SPURGEON Y, WU Q H, et al. An evidential reasoning approach to transformer condition assessments [J] IEEE Transaction Power Delivery, 2004, 19(4): 1696-1703

[3] XIONG Hao, SUN Cai-xin, ZHANG Yun, et al A hierarchical grey evaluation model for operation condition of power transformers [J] Automation of Electric Power Systems, 2007, 31(7): 55-60

[4] ZHAO Wen-qing, ZHU Yong-li, JIANG Bo, el al Condition assessment for power transformers by Bayes networks [J] High Voltage Engineering, 2008, 34(5): 1032-1039.

[5] CHEN Li-juan, HU Xiao-zheng. Statistic analysis on reliability of power transmission and transformation facilities in China in 2010 [J]. Electric Power, 2011, 44(6): 71-77.

[6] CHEN Li-juan, LI Xia. Statistic analysis on reliability of power transmission and transformation facilities in China in 2011 [J]. Electric Power, 2012, 45(7): 89-93.

[7] LIU Na, LIANG Guo-dong, WANG Liu-fang, et $d$. Failure mode effect and criticality analysis for condition maintenance of power transformer [J]. High Voltage Engineering, 2003, 29(2): 3-5, 8.

[9] CIGRE Working Group. Guidelines for life management technique for power transformer [S]. 2002.

[10] YU Qian, LI Wei-Guo, LUO Ri-Cheng. Research on qualitative method of power transformer condition assessment using analysis hierarchy process [J].Journal of Hunan University: Natural Sciences, 2011, 38(10): 56-60. 